\title{
Biogeochemistry of the Bay of Bengal: Physical, chemical and primary productivity characteristics of the central and western Bay of Bengal during summer monsoon 2001
}

\author{
M. Madhupratap*, Mangesh Gauns, N. Ramaiah, S. Prasanna Kumar, \\ P.M. Muraleedharan, S.N. de Sousa, S. Sardessai and Usha Muraleedharan ${ }^{\mathrm{a}}$ \\ National Institute of Oceanography, Dona Paula, Goa-403 004, India \\ ${ }^{\mathrm{a}}$ Department of Marine Science and Marine Biotechnology, Goa University, Goa, India
}

\begin{abstract}
Reliable data on biological characteristics from the Bay of Bengal are elusive. In this paper, we present results on physics, chemistry and biology simultaneously measured during the summer monsoon, 2001 from open ocean and coastal areas of the region. It was characterised by cold core eddies and thermocline oscillations. However, these were capped by prevalent low saline upper regime and prevented surfacing of nutrients. The river plume effects were evident from the low salinity values observed in the surface layers of the upper bay, but this did not bring-in significant amount of nutrients. The chlorophyll $a$ concentrations (10-20 $\mathrm{mg} \mathrm{m}^{-2}$ ) and primary productivity values (40-502 $\mathrm{mg}$ $\mathrm{C} \mathrm{m}^{-2} \mathrm{~d}^{-1}$ ) were low and not up to Arabian Sea values for the same season. Diatoms dominated the phytoplankton community and consisted of more number of genera compared to the Arabian Sea. Large colonies of the tunicate, Pyrosoma, which occurred at the surface as well as mid-depths could have consumed a part of the phytoplankton population. These results, albeit limited, have implications on the biogeochemistry of the region.
\end{abstract}

\section{Introduction}

The Arabian Sea (AS) and the Bay of Bengal (BOB) are twin seas caressing the western and eastern borders of the Indian subcontinent. The terrains look almost alike, both being enclosed in the north at similar latitudes. There are, however, many

*Corresponding author. Fax: +91-832-223340

E-mail address:madhu@csnio.ren.nic.in (M.Madhupratap) 
differences - the latter is partially connected to the Pacific through the Australasian seaways, contributing to physical, chemical and biological exchanges. Both lie in the tropics and are relatively small basins coming under the influence of the seasonally reversing monsoons. They form excellent crucibles to study the variability in the biogeochemistry of the oceans.

Differences between the physical and chemical regimes of AS and BOB arise mainly through (1) opposing trends in surface circulation during summer (southwest) and winter (northeast) monsoons (2) the BOB receives large quantities of fresh water from hinterland rivers (an imposing $1.6 \times 10^{12} \mathrm{~m}^{3} \mathrm{yr}^{-1}$ compared to $0.3 \times 10^{12} \mathrm{~m}^{3} \mathrm{yr}^{-1}$ in the AS, latter including the Indus; Subramanian, 1993) as well as oceanic precipitation making its upper layers less saline (annual mean $<34 \mathrm{psu}$ ). The associated suspended sediment discharge into the Bay is estimated to be $1.4 \times 10^{9}$ tonnes compared to about $200 \times 10^{6}$ tonnes in the AS.

Under the aegis of the JGOFS (Joint Global Ocean Flux Studies) AS was targeted as one of the prime areas for investigations along with the Atlantic, Pacific and Southern Ocean. Thus, over the recent past we have acquired substantial amount of data sets from the AS (Burkill et al., 1993; Burkill, 1999; Baars, 1994; Lal,1994; Krishnaswami and Nair, 1996; Gaur, 2000; Smith, 1998, 1999, 2000, 2001). On the other hand, after the International Indian Ocean Expedition (IIOE) during 1959-1965, despite many studies to understand the physical characteristics of the Bay of Bengal (for e.g., La Fond, 1957; Suryanarayana et. al., 1991; Murty et al., 1992; for more detailed reviews see Varkey et al., 1996; and Schott and McCreary, 2001), very few attempted to comprehend the water column chemistry (Sen Gupta et al., 1977; De Souza et al., 1981; Rao et al., 1994). Even fewer studies exist which address the biogeochemical characteristics of the Bay using collocated sampling and the overall information available remains scanty. For this reason, the Indian-JGOFS extended its studies from the AS to this region as a sequel, with an aim to cover seasonal and interannual changes and understand the processes which drive the biogeochemistry of the region (see the web site www.bobps.indian_ocean.org/bobps).

$\mathrm{BOB}$ is traditionally considered to have poorer biological productivity compared to its western counterpart - the AS. Although the riverine flux may bring in nutrients, they are thought to be lost to the deep because of its narrow shelf (Qasim, 1977; Sen 
Gupta et al., 1977; Radhakrishna et al., 1978). Comparatively heavier cloud cover during summer monsoon may be another reason for this. However, it is a cyclone-prone region and these episodic events are likely to churn-up the area, injecting nutrients to the shallow euphotic zone (shallow due to cloud cover and turbidity arising from sediment influx) and thereby enhance production in the upper layers.

In fact, it was postulated that higher surface production resulting from lower light intensities occurs in the $\mathrm{BOB}$ although the column production is much higher in the AS (Qasim, 1977). Primary productivity values ranging from 3.0 to $8.7 \mathrm{~g} \mathrm{C} \mathrm{m}^{-2} \mathrm{~d}^{-1}$ have been reported from the inshore waters of the east coast of India in June-July (Nair et al., 1973). Based on measurements during August-September $1978 \mathrm{chl} a$ up to $50 \mathrm{mg} \mathrm{m}^{-2}$ was reported inshore by Bhattathiri et al. (1980) and concluded that "the primary production of BOB is not less than that reported from the AS" (see also Pant,1992). Nonetheless, these values are exceptional, often referring to inshore blooms. On the contrary, most measurements are in effect less than $0.5 \mathrm{~g} \mathrm{~m}^{-2} \mathrm{~d}^{-1}$ along with very low chlorophyll $a$ (usually $<0.1 \mathrm{mg} \mathrm{m}^{-3}$ or $<10 \mathrm{mg} \mathrm{m}^{-2}$ ).

The BOB Process Studies were aimed to understand (1) whether the riverine inputs influence the upper ocean physical and chemical characters and spatio-temporal variability in production (2) how the altered features of the BOB compare with the AS and its biogeochemistry. With these aims, we undertook the first BOB Process Study during summer monsoon from July 6 to August 2, 2001, covering two transects, one in the open sea (along $\left.88^{\circ} \mathrm{E}\right)$ and another along the eastern coast of India $\left(81-85^{\circ} \mathrm{E}\right.$; Fig. 1). It may be pointed out that the coastal track was in fairly deep waters (depth often exceeding $1000 \mathrm{~m}$ ) because of the narrow shelf.

\section{Data and Methods}

A Sea-Bird Electronics CTD (Conductivity-Temperature-Depth) was employed to obtain profiles at one-degree intervals and to $1000 \mathrm{~m}$ depth on board the ORV Sagar Kanya. CTD salinity was calibrated against water samples collected simultaneously by a rosette sampler fitted with 30 litre Go Flo bottles and analyzed with a Guildline 8400 Autosal. The rosette was allowed a 1-minute stabilization before the bottles were closed to ensure that samples from desired depths were collected without any depth ambiguity. Surface meteorological parameters were measured continuously using the shipboard 
automatic weather station. The sea surface temperature (SST) was measured using a bucket-thermometer by keeping it as close to the water surface as possible without breaking the water surface. Water samples from various depths were analyzed for nitrate and silicate with a SKALAR auto-analyzer.

Apart from the high resolution one-degree sampling for physical and chemical observations, five stations in the open ocean and four stations along the western margin (Fig. 1) were occupied, each for over a day, for measuring primary productivity and related parameters. Water samples collected from eight discrete depths (near surface, $10,20 \mathrm{~m}$ and thereafter at $20 \mathrm{~m}$ intervals up to $120 \mathrm{~m}$ ) by the CTD rosette sampler were used for measuring primary production (PP), chlorophyll $a(\mathrm{Chl} a)$ and for estimating phytoplankton cell counts from these nine stations. The JGOFS Protocols (UNESCO, 1994) were followed for measuring all parameters.

For PP measurements water samples drawn at pre-dawn from the above mentioned depths were collected into four $300 \mathrm{ml}$ polycarbonate bottles (Nalgene, Germany) (three light, one dark) for each depth. One ampoule of $\mathrm{NaH}^{14} \mathrm{CO}_{3}$ (Board of Radiation and Isotope Technology, Mumbai with a specific activity of $185 \mathrm{kBq}$ ) was added to each bottle and incubated in-situ using a mooring system, at respective depths for 12 hours from just before sunrise to half an hour after sunset. Incorporation of ${ }^{14} \mathrm{C}$ was determined by filtering $100 \mathrm{ml}$ of sample from each bottle through GF/F filters $(25 \mathrm{~mm}$ dia, $0.7 \mu \mathrm{m}$ pore size, Whatman, USA). The filters were transferred to scintillation vials and exposed overnight to $\mathrm{HCl}(0.5 \mathrm{~N})$ fumes in a closed container. $5 \mathrm{ml}$ of liquid scintillation cocktail (Sisco Research Laboratory, Mumbai) was added to each vial and the radioactivity was measured in a scintillation counter (Wallac 1409 DSA, Perkin Elmer, USA). Primary production rate was calculated and expressed as $\mathrm{mg} \mathrm{C} \mathrm{m}^{-3} \mathrm{~d}^{-1}$, $12 \mathrm{~h}$ being considered as day (UNESCO, 1994).

Two replicates of 1.5 litre samples from the depths mentioned above were filtered through $47 \mathrm{~mm} \mathrm{GF} / \mathrm{F}$ filters and deep frozen immediately at $-20^{\circ} \mathrm{C}$. At the end of the cruise, all filters were transported to the shore laboratory in liquid nitrogen. Within a week, the chl $a$ was extracted in $10 \mathrm{ml} 90 \%$ acetone in the dark for $24 \mathrm{hrs}$ in a refrigerator and its concentration determined fluorometrically (Turner Designs, USA).

For an assessment of generic composition and cell counts of phytoplankton (size $>5 \mu \mathrm{m})$, water sample from each depth up to $60 \mathrm{~m}$ were fixed in Lugol's iodine $(1 \%$; 
$\mathrm{w} / \mathrm{v}$ ) and 3\% formaldehyde. Samples were stored in dark at low temperature until analyses. A settling and siphoning procedure was followed to concentrate samples from $250 \mathrm{ml}$ to $20 \mathrm{ml}$. Two $1 \mathrm{ml}$ replicates of concentrated samples were then examined microscopically in a Sedgewick-Rafter plankton counting chamber at 200x magnification. In addition to counting the phytoplankton, 1.5 to $3.0 \mathrm{ml}$ subsamples from the samples collected for bacterial abundance measurements (formalin preserved) from similar depths were examined for autofluorescing cells retained on polycarbonate membranes $(0.22 \mu \mathrm{m}$ pore size $)$. Autofluorescing picoplankters were enumerated using oil immersion objective on an epifluorescence microscope (Nikon E400, Japan) at 1000x.

\section{Results}

\subsection{Physical features}

Wind speeds, along $88^{\circ} \mathrm{E}$, were on an average about $6 \mathrm{~m} \mathrm{~s}^{-1}$ from $7^{\circ} \mathrm{N}$ to $13^{\circ} \mathrm{N}$ and increased further north to $10.5 \mathrm{~m} \mathrm{~s}^{-1}$. Wind direction varied from west to northwest (Fig. 1). Atmospheric pressure showed a steady decrease towards the north from $1013 \mathrm{mb}$ at $7^{\circ} \mathrm{N}$ to $1003 \mathrm{mb}$ at $20^{\circ} \mathrm{N}$. Except for the diurnal variability, air temperature did not show any significant variation, with an average value of $28.7^{\circ} \mathrm{C}$. SST was on an average $28.4^{\circ} \mathrm{C}$ between $7^{\circ} \mathrm{N}$ and $9^{\circ} \mathrm{N}$ and increased to $29.5^{\circ} \mathrm{C}$ at $11^{\circ} \mathrm{N}$. Mixed layer depth (MLD), calculated using the density criteria (Levitus, 1982), was in excess of $50 \mathrm{~m}$ at $12^{\circ} \mathrm{N}$ but shoaled under the influence of increasing freshening more or less gradually to less than $4 \mathrm{~m}$ at $20^{\circ} \mathrm{N}$ (Fig.2, and also shaded region in Fig. 6).

The vertical thermal structure in the upper $300 \mathrm{~m}$ showed oscillation within the thermocline (Fig. 2a). An upheaval of isotherms was noticed between $7^{\circ} \mathrm{N}$ and $11^{\circ} \mathrm{N}$ while north of it the isotherms showed a gradual shoaling towards $20^{\circ} \mathrm{N}$. In the former case, the $28^{\circ} \mathrm{C}$ isotherm shoaled from $80 \mathrm{~m}$ to $20 \mathrm{~m}$ and thus the upper thermocline showed a vertical displacement of about $60 \mathrm{~m}$, which tapered off towards the lower thermocline. This was clearly a signature of a subsurface cold core eddy, seen below $15 \mathrm{~m}$ depth, which depressed the ambient temperature at $60 \mathrm{~m}\left(27^{\circ} \mathrm{C}\right)$ by about $5^{\circ} \mathrm{C}$. Below $300 \mathrm{~m}$, the thermal structure did not show any special features.

The vertical salinity structure showed strong gradient in the upper 100m depth (Fig. 2b). In the surface layer, salinity was about 33.5 psu (practical salinity scale) between 
$7^{\circ} \mathrm{N}$ and $15^{\circ} \mathrm{N}$ but reduced rapidly towards north reaching a low of 27.6 psu at $17^{\circ} \mathrm{N}$. The salinity gradient in the upper $50 \mathrm{~m}$ at $7^{\circ} \mathrm{N}$ was about 1.5 psu while that at $20^{\circ} \mathrm{N}$ was about 7 psu, indicating the strong signal of freshwater influx in this region. Below 100m depth, the vertical salinity distribution showed almost homogeneous waters down to $1000 \mathrm{~m}$ (data not shown) with a salinity of $35 \mathrm{psu}$.

Along the coast, wind speeds were on an average $4 \mathrm{~m} \mathrm{~s}^{-1}$ except at $12^{\circ} \mathrm{N}$ and $18^{\circ} \mathrm{N}$ where it was about $9 \mathrm{~m} \mathrm{~s}^{-1}$. Wind direction varied from south to north-northwest with average winds being in a southwesterly direction (Fig. 1). As was the case of open ocean section, the atmospheric pressure also showed a decrease towards the north. Air temperature did not show any significant trend except for diurnal variability, with an average value of $28.5^{\circ} \mathrm{C}$. SST exhibited a $1^{\circ} \mathrm{C}$ drop from $11^{\circ} \mathrm{N}$ to $20^{\circ} \mathrm{N}$. Coastal SSTs were on an average $28.9^{\circ} \mathrm{C}$ and were higher than those at the open ocean stations of the corresponding latitude. MLD, which was $25 \mathrm{~m}$ at $11^{\circ} \mathrm{N}$ shoaled northwards to almost imperceptible levels (Fig.3, and also shaded region in Fig.6).

The thermal structure in the upper $300 \mathrm{~m}$ along the coastal section also exhibited oscillations within the thermocline (Fig. 3a) as was the case with the open ocean transect. A noteworthy feature was, again, an uplifting of isotherms centered at $17^{\circ} \mathrm{N}$, $83.5^{\circ} \mathrm{E}$. The $28^{\circ} \mathrm{C}$ isotherm shoaled from $60 \mathrm{~m}$ to $10 \mathrm{~m}$ (Fig. 3a). This vertical displacement of about $50 \mathrm{~m}$ in the upper thermocline depressed the ambient temperature by about $5^{\circ} \mathrm{C}$. Although we did not observe any upwelling signature in this section in terms of cold and high salinity waters in the upper layers, this could be because our western boundary stations sampled waters much farther away from the coast/shelf.

Vertical salinity structure in the upper $300 \mathrm{~m}$ along the coast also showed strong salinity gradient in the top $100 \mathrm{~m}$ depth (Fig. 3b) and homogeneous waters with 35 psu salinity below it and up to $1000 \mathrm{~m}$. But unlike the open ocean, the salinity gradient south of $15^{\circ} \mathrm{N}$ was weaker ( $0.5 \mathrm{psu}$ as compared to 1.5 for the open ocean). In the surface layer the average salinity was 33.7 psu up to $16^{\circ} \mathrm{N}$ but reduced northward, with the lowest value of $29.6 \mathrm{psu}$ at $19^{\circ} \mathrm{N}$.

\subsection{Nutrients}

Vertical distribution of nitrate showed that in general the upper 30m was devoid of nitrate and this situation deepened up to $50 \mathrm{~m}$ between $12^{\circ} \mathrm{N}$ and $15^{\circ} \mathrm{N}$ (Fig. 4a). The 
$1 \mu \mathrm{M}$ isopleth showed shoaling under the influence of the subsurface cold core eddy and towards the north the shoaling was concurrent with that of the isotherms (Fig. 2a). In general, nitracline was situated between 50 and 100m depth. A second region of strong gradient (of about 30m thickness) was seen around 200m. Silicate distributions were also similar to that of nitrate, except for a high concentration of more than $2 \mu \mathrm{M}$ in the north (Fig. 4b). This indicated the signature of fresh water influx from the north.

Nitrate distribution along the coastal section showed that the upper $40 \mathrm{~m}$ was devoid of nitrate except in the north (Fig. 5a). However, under the influence of the cold core eddy signature seen in the thermal structure (Fig. 3a), we noticed shoaling of nitracline as was evident from the $1 \mu \mathrm{M}$ isopleth which shoaled up to $30 \mathrm{~m}$ between $16^{\circ} \mathrm{N}$ to $18^{\circ} \mathrm{N}$. Below the nitracline, the pattern remained the same as that of the open ocean. Silicate distribution was also similar to that of nitrate, except for the presence of high surface silicate $(>4 \mu \mathrm{M})$ in the north (Fig. 5b) as in the case of open ocean section. Phosphates were generally at undetectable levels in the upper 30m throughout the area of study.

\subsection{Biological characteristics}

Concurrent with nutrient distribution, surface chl $a$ was poor $\left(0.06\right.$ to $0.28 \mathrm{mg} \mathrm{m}^{-3}$ in open waters and 0.06 to $0.16 \mathrm{mg} \mathrm{m}^{-3}$ towards the coast, Fig. 6a,b). Satellite (Sea-Wifs) derived pigment concentrations for the monthly composition of July 2001, (T. Suresh, pers. comm.) also showed similar surface values of ranging from 0.1 to $0.3 \mathrm{mg} \mathrm{m}^{-3}$ in the sampled region. Higher surface values were towards north and so were the column integrated values (range 10-20 $\mathrm{mg} \mathrm{m}^{-2}$, Fig. 7). A subsurface chlorophyll maximum (SCM) was encountered at most stations (Fig. 6 a,b) usually below the mixed layer and associated with the nutricline $(\sim 40 \mathrm{~m})$. On an average, about $37 \%$ of chl $a$ occurred in the MLD while $28 \%$ occurred at the SCM depth. Only in the northern most open ocean station $\left(20^{\circ} \mathrm{N}\right)$ a decrease in chl $a$ with depth in the upper layers was observed where it was uniformly $0.28 \mathrm{mg} \mathrm{m}^{-3}$ upto $10 \mathrm{~m}$ depth. It might be that the low salinity associated with a virtually non-existent mixed layer caused this. There were no clear differences between open and coastal waters, except that $20 \%$ of chl a occurred below $80 \mathrm{~m}$ compared to $13 \%$ in open waters. 
Column integrated PP was between 90 and $220 \mathrm{mg} \mathrm{C} \mathrm{m}^{-2} \mathrm{~d}^{-1}$ along $88^{\circ} \mathrm{E}$, but relatively higher range was obtained along the coastal transect (328-520 $\left.\mathrm{mg} \mathrm{C} \mathrm{m}^{-2} \mathrm{~d}^{-1}\right)$ except for a low $40 \mathrm{mg} \mathrm{C} \mathrm{m}^{-2} \mathrm{~d}^{-1}$ at $15^{\circ} \mathrm{N}$ (Fig. 7). PP within the mixed layer was about $54 \%$ of the total while below $80 \mathrm{~m}$ it was insignificant $(8 \%$ in both coastal and open waters). About $26 \%$ of the PP was associated with the SCM. The productivity to chl $a$ ratio was between 10 and 20 although a few higher values (up to 40) occurred at some coastal stations (Fig. 7). A significant correlation $(\mathrm{r}=0.58 ; P<0.001 ; \mathrm{n}=72)$ between chl $a$ and primary productivity rate was observed (Fig. 8) showing that most of the productivity was related to the active chl $a$ present in the water column.

Along the open ocean the phytoplankton cell counts were the highest at $20^{\circ} \mathrm{N}$ ranging from $13.8 \times 10^{3} 1^{-1}$ at surface (corresponding to chl $a$ estimates) to $0.6 \times 10^{3} 1^{-1}$ at $60 \mathrm{~m}$. They showed a general decrease southward, with their lowest abundance at $15^{\circ}$ $88^{\circ} \mathrm{E}$ (Fig. 9). At stations south of $15^{\circ} \mathrm{N}$, their counts were higher in the upper $10 \mathrm{~m}$ and decreased drastically below this. Along the western margin the highest counts were observed from samples collected at $19^{\circ} \mathrm{N} 85^{\circ} \mathrm{E}$ and the lowest at $15^{\circ} \mathrm{N} 81^{\circ} \mathrm{E}$ (Fig. 9). Their counts kept increasing with increasing depth at $12^{\circ} \mathrm{N} 81^{\circ} \mathrm{E}$ for reasons unknown. Similar to discrete depth variations, the column integrated numbers clearly indicated their preponderance in the north. In general, the phytoplankton counts, chl $a$ concentration and primary productivity ratio along both transects showed co-variation. Picoplankton abundance was generally higher along $88^{\circ} \mathrm{E}$ with a range of $0.24 \times 10^{7} 1^{-1}$ to $18.5 \times 10^{7} 1^{-1}$ compared to coastal areas except a high $\left(9.4 \times 10^{7} 1^{-1}\right.$ at $\left.40 \mathrm{~m}\right)$ in the north at $19^{\circ} \mathrm{N} 85^{\circ} \mathrm{E}$ (data not shown).

Diatoms dominated the phytoplankton population both in open and coastal waters ( $>90 \%$, Table 1, depicted from 2 representative stations). Biddulphia, Chaetoceros, Thallasiothrix, Thallassionema, Schroderella, Navicula and Nitzchia were the common genera. A few genera of dinoflagellates, usually Peridinium and Ceratium occurred.

Zooplankton biomass (collected at mid-day and midnight from different strata up to $1000 \mathrm{~m}$ using a Hydro-Bios Multiple Plankton Net with a mesh size of $200 \mu \mathrm{m}$ ) at the 9 PP stations was generally concentrated in the MLD and rapidly diminished with depth especially below the lower thermocline ( $82 \%$ of the biomass in oceanic waters and $59 \%$ in coastal areas was above the thermocline; for sampling strategy and biomass conversion to carbon see Madhupratap et al., 2001). Day-night biomass did not show 
any particular pattern. The biomass in the upper $1000 \mathrm{~m}$ varied usually from 18 to $400 \mathrm{~m}$ mol C m${ }^{-2}$ in open waters and 12 to $1070 \mathrm{~m} \mathrm{~mol} \mathrm{C} \mathrm{m}^{-2}$ in the western boundary. But, we could not realistically estimate the biomass at most of the open ocean station and one along the coast $\left(11^{\circ} \mathrm{N}, 81^{\circ} \mathrm{E}\right)$ because huge colonies of the tunicate Pyrosoma occurred which could not be separated from other zooplankton. These large colonies also occurred without any day-night pattern (given that the ship drift over $12 \mathrm{hr}$ would have sampled different, but adjacent areas). Pyrosome colonies were seen at times in the surface and inexplicably in layers below up to $500 \mathrm{~m}$ depth and the biomass at these depths $\left(>1000 \mathrm{~m} \mathrm{~mol} \mathrm{C} \mathrm{m}^{-2}\right.$ ) led to exceeding values in comparison to conventional estimates. Otherwise, the zooplankton were dominated by copepods - Paracalanus, Clausocalanus and Eucalanus (calanoids) being the common genera plus the carnivorous Oithona (Cyclopoid) and Oncaea (Poecilostomatoid) comprising the composition.

\section{Discussion}

The investigation was conducted during the summer monsoon when the rivers of India are in spate and discharge large quantities of freshwater into the adjacent seas, particularly the Bay of Bengal. The rainfall during the year 2001 showed a normal summer monsoon season (Indian Meteorological Department; www.tropmet.res.in). The effects of the river plume were evident in the northern regions where the highest discharge arises out of the Ganges - Brahmaputra - Irrawadi rivers (Subramanian, 1993), reducing the surface salinity to ca. 28 psu or lower.

A significant feature observed from the thermal structure, both along the open ocean and western boundary was the presence of thermocline oscillations and cold core eddy signatures. Oscillations similar to present observations were recorded by Rao et al. (1983) from a time series measurement at $7.5^{\circ} \mathrm{N}$ and $87.5^{\circ} \mathrm{E}$ during May 1979. The formation of eddies was also noticed close to the western boundary in July 1984 (Babu et al., 1991). Apart from these, we also observed a northward shoaling of isotherms north of $12^{\circ} \mathrm{N}$ along the open ocean section. Under the influence of these eddies not only the subsurface cold waters but nutrients as well were pumped into the upper subsurface layers. Consistent with the northward shoaling of isotherms in the open ocean section, nitrate as well as silicate isopleths also showed shoaling. However, the 
lense of 2-4 $\mu \mathrm{M}$ silicate in the surface layers, detached from the subsurface, in the northern most region sampled in both sections showed that this was a feature much closer to the coast in the north and did not arise out of upward pumping. In fact, the effects would be more in the inshore/shelf waters which we did not sample. Results obtained by Rao et al., 1994 in March-April (a dry season) and December (cycloneprone) from shelf to offshore did not show presence of nitrate in the upper layers and concluded that rivers flowing into the Bay might not contribute much to the inorganic nutrient pool. This is in confirmation with earlier results obtained by De Sousa et al. (1981) and Rajendran et al. (1980) during south west monsoon and that a considerable part of the terrigenous humus is lost at its confluence with the sea (Sen Gupta et al., 1977). The upper low salinity layer caused distinct stratification in summer resulting in generally shallow MLDs, despite favorable wind speeds which should have resulted in deeper mixed layers.

Thus, both eddies and shoaling isotherms were capped by the low saline layer leading to a failure of their surfacing and prevented nutrients reaching the upper $(40 \mathrm{~m}$ or so) layers. Neither did the river plume bring in appreciable nutrients southward or these were consumed within the estuary or inshore waters. Localised, mild upwelling along the southern part of the western boundary during summer had been reported by Murthy and Varadachari (1968) and De Sousa et al. (1981). Later Shetye et al. (1991) suggested upwelling along the east coast of India during summer, in an approximately $40 \mathrm{~km}$ wide band, but they also showed that river discharge in the north overwhelms signatures of upwelling.

The biological features were consistent with the observed physical and chemical regimes. The low chl $a$ and PP dovetail with low ambient nutrients. Reduced irradiance and heavy sediment discharge in this season shallows the euphotic depths to $6 \mathrm{~m}$ (inshore) and to about 20-40m (open ocean) in this season (Qasim, 1979). Even cyclone created perturbations are bound to result in the same. We are yet to measure these from other seasons, nevertheless, our first conclusions are that the BOB is less productive in 
early summer in comparison to the AS.

Earlier reports of Qasim (1979), Bhattathiri et al. (1980) and Devassy et al. (1983) indicate that chlorophyll $a$ concentrations varied widely without showing any geographic or seasonal patterns. Radhakrishna et al. (1978) reported surface chlorophyll $a$ to range from 0.084 to $1.67 \mathrm{mg} \mathrm{m}^{-3}$ and euphotic column values from 8.63 to 28.45 $\mathrm{mg} \mathrm{m}^{-2}$ during 1976 summer monsoon. For the 1978 summer monsoon, the column chlorophyll $a$ in euphotic zone ranged from 1.28 to $33.72 \mathrm{mg} \mathrm{m}^{-2}$ in the offshore waters (Bhattathiri et al., 1980) and from 0.01 to $1.01 \mathrm{mg} \mathrm{m}^{-3}$ in the surface waters. Concentrations were in the range of 2.11 to $23.60 \mathrm{mg} \mathrm{m}^{-2}$ during 1977 monsoon months and the surface concentrations varied from as low as 0.03 to a high of $1.04 \mathrm{mg} \mathrm{m}^{-3}$ (Devassy et al., 1983). The high value observed by them was attributed to a diatom bloom predominated by Thallassiosira subtilis. The observed range of surface chl $a$ in the present study was low compared to some of the earlier reports and was in the range of 0.06 to $0.28 \mathrm{mg} \mathrm{m}^{-3}$. The SCM seen at most stations is consistent with observations from the Bay during May-June, 1996 (Murty et al., 2000); the pigment concentrations at the SCM were found to be an order of magnitude higher than those at the surface. The range observed was similar to ours being 0.01 to $0.2 \mathrm{mg} \mathrm{m}^{-3}$. However, Gomes et al. (2000) report that $\mathrm{Chl} a$ and production rates could go as high as $53 \mathrm{mg} \mathrm{m}^{-2}$ and $4.5 \mathrm{~g}$ $\mathrm{C} \mathrm{m}^{-2} \mathrm{~d}^{-1}$ in March-April, a season with very less run-off. But, Sen Gupta et al. (1977) show that there are no detectable nitrates in the upper layers of the BOB along the western region in this season as well. During summer monsoon the values of chl $a$ were higher up to $92 \mathrm{mg} \mathrm{m}^{-2}$ but PP on the other hand remained low $\left(0.3 \mathrm{~g} \mathrm{C} \mathrm{m}^{-2} \mathrm{~d}^{-1}\right)$. Gomes et al. (2000) attributed the reason for this to the cloud cover.

Historical measurements of PP from the Bay date back to Galathea Expedition of the 1951 followed by the Anton Brunn expedition. These measurements show values of 0.1 to $0.3 \mathrm{mg} \mathrm{C} \mathrm{m}^{-2} \mathrm{~d}^{-1}$ in the deep and 0.01 to $2.16 \mathrm{~g} \mathrm{C} \mathrm{m}^{-2} \mathrm{~d}^{-1}$ in shelf region. Later values reported from offshore regions are from $129.99-329.45 \mathrm{mg} \mathrm{C} \mathrm{m}^{-2} \mathrm{~d}^{-1}$ (av. 219.79) during August-September 1976 (Radhakrishnan et al., 1978) and from 180 to $2200 \mathrm{mg} \mathrm{C} \mathrm{m}^{-2} \mathrm{~d}^{-1}$ (av. $740 \mathrm{mg} \mathrm{C} \mathrm{m} \mathrm{d}^{-1}$ ) during Aug-Sept 1978 (Bhattathiri et al., 1980). In the slope region along the western margin of the Bay, the PP during AugustSeptember, 1976 was in the range of $49.66-606.37 \mathrm{mg} \mathrm{C} \mathrm{m}^{-2} \mathrm{~d}^{-1}$ (av. $315.43 \mathrm{mg} \mathrm{C} \mathrm{m}^{-2}$ 
$\mathrm{d}^{-1}$ ) and during Aug-Sept 1978, it was 120 to $3410 \mathrm{mg} \mathrm{C} \mathrm{m}^{-2} \mathrm{~d}^{-1}$ (av. $1280 \mathrm{mg} \mathrm{C} \mathrm{m}^{-2} \mathrm{~d}^{-1}$ ). However, these were made before trace-metal clean techniques were available and a recalculation shows that the PP to chl $a$ ratios are mostly lopsided often exceeding 250 and up to $>2500$ (except Radhakrishna et al., 1978). Thus we do not reconcile totally with available earlier data, but concede that inshore/coastal measurements are lacking in our observations.

With clean-techniques and standardization of in-situ incubation protocols, reliable measurements of PP during the last decade from various parts of the world oceans are available (see Letelier et al., 1996, Barber et al., 2001). Since the present data set gives the first in-situ measurements from the Bay, more recent southwest monsoon data available from the Arabian Sea are compared in Table 2. Clearly the PP in the Bay is much lower than those observed in the Arabian Sea during this season. The PP in the Bay during southwest monsoon of 2001 was more comparable to those observed during the oligotrophic Spring-Intermonsoon in the Arabian Sea when SSTs are high $\left(28-29^{\circ} \mathrm{C}\right.$ and comparable to the present study) and mixed layer shoals and attains more or less the characteristics of a Typical Tropical Structure (Madhupratap et al., 1996, 2001). Unlike the BOB, in the AS strong upwelling along the western boundary and in the open ocean during southwest monsoon (Prasanna Kumar et al., 2001) bring nutrients up into the euphotic zone enhancing productivity.

The numerical abundance of phytoplankton ranged from $0.41 \times 10^{8}$ to $7.1 \times 10^{8} \mathrm{~m}^{-2}$ during the present study. Somewhat paradoxically, this range is comparable to those reported earlier from the central and eastern Arabian Sea $\left(0.3 \times 10^{8}\right.$ to $10 \times 10^{8} \mathrm{~m}^{-2}$; Sawant and Madhupratap, 1996) during southwest monsoon of 1995. Similarly, contribution of diatoms to the total phytoplankton was significantly large in both areas. Nitrate rather than silicate seem to control PP in both regions. However, the number of genera of diatoms found in BOB (26) was higher than those found in the AS (9) thus showing higher diversity. There could be a reason for this; as food becomes scarcer, as may be the case in BOB, allopatric or even sympatric speciation is found in deep-sea copepods leading to higher diversity (Madhupratap et al., 1990). This plus salinity variations in the Bay might result in niche separation and we already know that composition of species of fish in this area is quite different from that of AS (CMFRI, 1995). It is speculative, but at the moment we do not have better explanations. The 
population of autotrophic dinoflagellates was low in the Bay. They formed $\sim 5 \%$ of the total phytoplankton community in the oceanic waters (Table 1). Higher primary productivity value associated with high chlorophyll $a$ concentration at northern most coastal station $\left(19^{\circ} \mathrm{N} 85^{\circ} \mathrm{E}\right)$ was reflected in the total phytoplankton cell counts as well.

Zooplankton biomass obtained from the upper 1000m of the AS (Madhupratap et

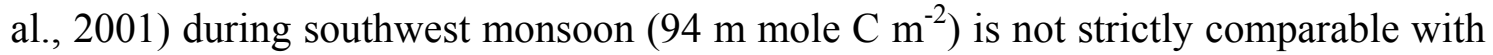
those from present study because of the large pyrosome colonies. Otherwise the common genera of copepods present in the two regions were more or less same. Incidentally, the pyrosomes are voracious mucous/filter feeders and are a counter part of the salp swarms very frequently found in the AS during summer and winter. This could also have led to the observed reduction in phytoplankton biomass through grazing.

All these bring us to some other questions pertaining to the biogeochemistry of the BOB. The fact remains that the productivity of the BOB remains an enigma with conflicting reports over seasons and areas. Obviously, this single report covering a very short period is not resolving it. But, it would seem that it is consistent with observed earlier reports on nutrient data. Some upwelling could happen inshore in some areas as indicated earlier and lead to higher productivity. But the overall annual picture is yet to emerge.

An oxygen minimum zone (OMZ) between 100 and 500m, less thick compared to the AS occurs in the BOB (Olson et al., 1993). One of the reasons attributed to cause the $\mathrm{OMZ}$ in the AS is the flux and decomposition of organic particles brought into the deep derived from the overlying productive waters. If the production in the BOB is lower, how does this happen in these waters? And, BOB does not make significant contribution to the water column denitrification which arises as a result of OMZ unlike the AS (see Rao et al., 1994, for a discussion). Another puzzle is that the average annual fluxes into the deep are comparable both in AS and BOB. However, lithogenic fluxes are more in the Bay and increase in fluxes are associated with increase in river discharge (Ittekkot et al., 1991; Ramaswamy and Nair, 1994). It may be that biogenic matter is more rapidly scavenged along with those of terrigeneous origin and ballast the material resulting in faster sedimentation to the deep (Ittekkot et al., 1992; Kumar et al., 1998). And thus, it may be fluvial matter (organic and undecomposed matter as 
indicated by Sen Gupta et al., 1977) which might be contributing more to the fluxes. Some of these questions along with interannual variability will be addressed in more detail in the forthcoming cruises of BOB Process Studies.

\section{Acknowledgements}

We thank Department of Ocean Development, New Delhi, for the financial support. This work was carried out as a part of Bay of Bengal Process Studies programme. We are thankful to all the cruise participants (Mr. G. Nampoothiri, Ms. Rochelle Da Costa, Mr. Jayshankar De, Mr. Damodar Shenoi, Mr. Fraddry D'Souza, Mr. Shripad Kunkolenkar, Ms. Nisha Pires, Ms. Avina Barretto, Ms. Xavita Vaz, Ms. Karen Lobo and Ms. Loretta Fernandes for their efficient co-operation and help on board. We also appreciated the help of Mr. A. Mahale in preparing the figures. This is NIO contribution number 3744. 


\section{References}

Baars, M.A. (Ed.) 1994. Monsoons and pelagic systems. Report on three cruises of RV Tyro in the Somali Current, the Gulf of Aden and the Red Sea during the southwest monsoon of 1992 and the northeast monsoon of 1993. Netherlands Indian Ocean Programme. National Museum of Natural History, Leiden, pp 143.

Babu, M.T., Prasanna Kumar, S., Rao, D.P., 1991. A subsurface cyclonic eddy in the Bay of Bengal. Journal of Marine Research 49, 403-410.

Barber, R.T., Marra, J., Bidigare, R.C., Codispoti, L.A., Halpern, D., Johnson, Z., Latasa, M., Goericke, R., Smith, S.L., 2001. Primary productivity and its regulation in the Arabian Sea during 1995. Deep-Sea Research II 48, 1127-1172.

Bhattathiri, P.M.A., Devassy, V.P., Radhakrishna, K., 1980. Primary production in the Bay of Bengal during southwest monsoon of 1978. Mahasagar-Bulletin of the National Institute of Oceanography 13, 315-323.

Bhattathiri, P.M.A., Pant, A., Sawant, S., Gauns, M., Matondkar, S.G.P., Mohanraju, R., 1996. Phytoplankton production and chlorophyll distribution in the eastern and central Arabian Sea in 1994-95. Current Science 71, 857-862.

Burkill, P.H. (Ed.) 1999. Arabesque: UK JGOFS Process Studies in the Arabian Sea. Deep-Sea Research II 46, pp. 529-863.

Burkill, P.H., Mantoura, R.F.C., Owens, N.J.P., 1993. Biogeochemical cycling in the northwestern Indian Ocean. Deep-Sea Research II 40, 643-849.

CMFRI (Central Marine Fisheries Research Institute), 1995, Marine Fisheries Information Service 136, pp 30.

Devassy, V.P., Bhattathiri, P.M.A., Radhakrishna, K., 1983. Primary production in the Bay of Bengal during August, 1977. Mahasagar-Bulletin of National Institute of Oceanography 16, 443-447.

De Sousa, S.N., Naqvi, S.W.A., Reddy, C.V.G., 1981. Distribution of nutrients in the western Bay of Bengal. Indian Journal of Marine Sciences 10, 327-331.

Gaur, V.K. (Ed.) 2000. Special issue on the International JGOFS symposium on Biogeochemistry of the Arabian Sea. Proceeding of the Indian Academy of Sciences (Earth and Planetary Science), 109, 393-537. 
Gomes, H.R., Goes, J.I., Saino, T., 2000. Influence of physical processes and freshwater discharge on the seasonality of phytoplankton regime in the Bay of Bengal. Continental Shelf Research 20, 313-330.

Ittekkot, V., Nair, R.R., Honjo, S., Ramaswamy, V., Bartsch, M., Manganini, S., Desai, B.N., 1991. Enhanced particle fluxes in Bay of Bengal induced by injection of fresh water. Nature 351, 385-387.

Ittekkot, V.B., Haake, B., Bartsch, M., Nair, R.R., Ramaswamy, V., 1992. Organic carbon removal in the sea: The continental connection. Upwelling Systems: Evolution since the early Miocene. pp. 167-176, Geological Society of London, Special Publication No. 64.

Krishnaswami, S., Nair, R.R. (Eds.) 1996. JGOFS (India). Current Science 71, 831-905.

Kumar, M.D., Sarma, V.V.S.S., Ramaiah, N., Gauns, M., De Sousa, S.N., 1998. Biogeochemical significance of transparent exopolymer particles in the Indian Ocean. Geophysical Research Letters 25, 81-84

La Fond, E.C., 1957. Oceanographic studies in the Bay of Bengal. Proceedings of the Indian Academic Sciences (Earth and Planetary Sciences) 46B, 1-46.

Lal, D. (Ed.) 1994. Biogeochemistry of the Arabian Sea, Indian Academy of Sciences, Bangalore, pp 253.

Letelier, R.M., Dore, J.E., Winn, C.D., Karl, D.M., 1996. Seasonal and interannual variations in photosynthetic carbon assimilation at station ALOHA. Deep-Sea Research II 43, 467-490.

Levitus, S., 1982. Climatological Atlas of the world ocean. NOAA Professional paper 13.

Madhupratap, M., Haridas, P., 1990. Zooplankton, especially calanoid copepods, in the upper 1000m of the south-east Arabian Sea. Journal of Plankton Research 12, 305321.

Madhupratap, M., Prasanna Kumar, S., Bhattathiri, P.M.A., Kumar, M.D., Raghukumar, S., Nair, K.K.C., Ramaiah, N., 1996. Mechanism of biological response to winter cooling in the northwestern Arabian Sea. Nature 384, 549-552.

Madhupratap, M., Gopalakrishnan, T.C., Haridas, P., Nair, K.K.C., 2001. Mesozooplankton biomass, composition and distribution in the Arabian Sea during 
fall intermonsoon: implications of oxygen gradients. Deep-Sea Research II 48, 13451368.

Murty, C.S. and Varadachari, V.V.R., 1968. Upwelling along the east coast of India, Bulletin of National Institute of Sciences India 36, 80-86.

Murty, V.S.N., Gupta, G.V.M., Sarma, V.V., Rao, B.P., Jyothi, D., Shastri, P.N.M., Supraveena, Y., 2000. Effect of vertical stability and circulation on the depth of the chlorophyll maximum in the Bay of Bengal during May-June, 1996. Deep-Sea Research I 47, 859-873.

Murty, V.S.N., Sarma, Y.V.B., Babu, M.T., Rao, D.P., 1992. Hydrography and circulation in the northwestern Bay of Bengal during the retreat of southwest monsoon. Proceedings of the Indian Academy of Sciences (Earth and Planetary Sciences) 101, 67-75.

Nair, P.V.R., Samuel, S., Joseph, K.J., Balachandran, V.K., 1973. Primary production and potential fishery resources in the seas around India. In: Proceedings of the symposium on 'Living resources of the seas around India', 1968, pp. 184-98. Special publication. Cochin: Central Marine Fisheries Research Institute.

Olson, D.B., Hitchcock, G.L., Fine, R.A., Warren, B.A., 1993. Maintenance of lowoxygen layer in the central Arabian Sea. Deep-Sea Research II 40, 673-683.

Owens, N.J.P, Burkill, P.H., Mantoura, R.F.C., Woodward, E.M.S., Bellan, I.E., Aiken, J., Howland, R.J.M., Llewellyn, C.A., 1993. Size-fractionated primary production and nitrogen assimilation in the western Indian Ocean. Deep-Sea Research II 40, 697-709.

Pant, A., 1992. Primary productivity in coastal and off-shore waters of India during two southwest monsoons, 1987 and 1989. In: Desai, B.N. (Ed.) Oceanography of the Indian Ocean, Oxford and IBH, New Delhi, 81-90.

Prasanna Kumar, S., M. Madhupratap, Kumar, M.D., Muraleedharan, P.M., de Souza, S. N., Gauns M., Sarma, V.V.S.S., 2001. High biological productivity in the central Arabian Sea during the summer monsoon driven by Ekman pumping and lateral advection. Current Science 81, 1633-1638.

Qasim, S.Z., 1977. Biological productivity of the Indian Ocean. Indian Journal of Marine Sciences 6, 122-137. 
Qasim, S.Z., 1979. Primary production in some tropical environments. In: Dunbar, M.J. (Ed.) Marine Production Mechanisms, pp.31-69. International Biological Programme 20, Cambridge University Press, Great Britain.

Radhakrishna, K., Devassay, V.P., Bhargava, R.M.S., Bhattathiri, P.M.A., 1978. Primary production in the Northern Arabian Sea. Indian Journal of Marine Sciences 7, 271275.

Rajendran, A., Rajagopal, M.D., Reddy, C.V.G., 1980. Distribution of dissolved silicate in the Arabian Sea and Bay of Bengal. Indian Journal of Marine Sciences 9, 172-178.

Ramaswamy, V., Nair, R.R., 1994. Fluxes of material in the Arabian Sea and Bay of Bengal - Sediment trap studies. Proceedings Indian Academy of Sciences (Earth Planetary Sciences) 103, 189-210.

Rao, C.K., Naqvi, S.W.A., Kumar, M.D., Varaprasad, S.J.D., Jayakumar, D.A., George, M.D., Singbal, S.Y.S., 1994. Hydrochemistry of the Bay of Bengal: possible reasons for a different water-column cycling of carbon and nitrogen from the Arabian Sea. Marine Chemistry 47, 279-290.

Rao, R.R., Rao, D.S., Murthy, D.S., Joseph, M.X., 1983. A preliminary investigation of the summer monsoonal forcing on the thermal structure of upper Bay of Bengal during MONEX-79. Mausam 34, 239-250.

Sawant, S., Madhupratap, M., 1996. Seasonality and composition of phytoplankton in the Arabian Sea. Current Science 71, 869-873.

Schott, F.A., McCreary, J.P., 2001. The monsoon circulation of the Indian Ocean. Progress in Oceanography 51, 1-23.

Sen Gupta, R., De Sousa, S.N., Joseph, T., 1977. On nitrogen and phosphorous in the western Bay of Bengal. Indian Journal of Marine Sciences 6, 107-110.

Shetye, S.R., Shenoi, S.S.C., Gouveia, A.D., Michael, G.S., Sundar, D., Nampoothiri, G., 1991. Wind-driven coastal upwelling along the western boundary of the Bay of Bengal during the southwest monsoon. Continental Shelf Research 11, 1397-1408.

Smith, S.L. (Ed.) 1998. 1994-1996 Arabian Sea Expedition: Oceanic Response to Monsoonal Forcing Part 1. Deep-Sea Research II 45, pp. 1905-2501.

Smith, S.L. (Ed.) 1999. 1994-1996 Arabian Sea Expedition: Oceanic Response to Monsoonal Forcing Part 2. Deep-Sea Research II 46, pp. 1531-1964. 
Smith, S.L. (Ed.) 2000. 1994-1996 Arabian Sea Expedition: Oceanic Response to Monsoonal Forcing Part 3. Deep-Sea Research II 47, pp. 1177-1677.

Smith, S.L. (Ed.) 2001. 1994-1996 Arabian Sea Expedition: Oceanic Response to Monsoonal Forcing Part 4. Deep-Sea Research II 48, pp. 1069-1402.

Subramanian, V., 1993. Sediment load of Indian rivers. Current Science 64, 928-930.

Suryanarayana, A., Murty, V.S.N., Sarma, Y.V.B., Babu, M.T., Rao, D.P., Sastry, J.S., 1991. Hydrographic features of the western Bay of Bengal in the upper $500 \mathrm{~m}$ under the influence of NE and SW monsoons. In: Desai, B.N. (Ed.), Oceanography of the Indian Ocean. Oxford \& IBH Publishing Co. Pvt. Ltd., New Delhi, pp. 595-604.

UNESCO. 1994. Protocols for the Joint Global Ocean Flux Study (JGOFS). Manual and Guides 29, pp. 170.

Varkey, M.J., Murty, V.S.N., Suryanarayana, A., 1996. Physical Oceanography of the Bay of Bengal and Andaman Sea. In: Ansell, A.D., Gibson, R.N., Barnes, M. (Eds.), Oceanography and Marine Biology: an Annual Review. University College London Press, London, pp. 1-70.

Veldhuis, M.J.W., Kraay, G.W., Van Bleijswijk, J.D.L., Baars, M.A., 1997. Seasonal and spatial variability in phytoplankton biomass, productivity and growth in the northwestern Indian ocean: the southwest and northeast monsoon, 1992-1993. DeepSea Research I 44, 425-449. 
Legends to figures

Fig. 1. Location map showing the stations along open ocean $\left(88^{\circ} \mathrm{E}\right)$ and coastal track. Dark circle indicate 1-degree CTD stations while hollow circle are the biological stations for $i n-s i t u$ incubation for primary production. The arrows are the observed wind vectors at stations.

Fig. 2. Vertical section of (a) temperature $\left({ }^{\circ} \mathrm{C}\right)$ and (b) salinity (psu) along open ocean $\left(88^{\circ} \mathrm{E}\right)$ track.

Fig. 3. Same as Fig.2 but along coastal track.

Fig. 4 Vertical section of (a) nitrate $(\mu \mathrm{m})$ and (b) silicate $(\mu \mathrm{m})$ along open ocean $\left(88^{\circ} \mathrm{E}\right)$ track. Note the change in contour interval of dashed line.

Fig. 5. Same as Fig. 4 but along coastal track.

Fig. 6.Vertical profiles of primary production (solid circles) and chlorophyll $a$ (open circles) in (a) oceanic (b) coastal stations (shown by lat., long.). Mixed layer depths are shown as shaded areas.

Fig. 7. Integrated concentrations of chlorophyll $a$ ( $\left.\mathrm{chl} a, \mathrm{mg} \mathrm{m}^{-2}\right)$, primary production (PP, mg C m $\mathrm{m}^{-2}$ ) and PP to chl $a$ ratios over $120 \mathrm{~m}$ in the oceanic and coastal waters.

Fig. 8. Relationship between chlorophyll $a\left(\mathrm{mg} \mathrm{m}^{-3}\right)$ concentrations and primary production $\left(\mathrm{mg} \mathrm{C} \mathrm{m}^{-3} \mathrm{~d}^{-1}\right)$.

Fig. 9. Depth distribution of phytoplankton cell density (nos. $x 10^{3} 1^{-1}$ ) in the Bay of Bengal during July-August 2001. 
Table 1

Generic composition of diatoms and dinoflagellates at two representative stations (0$60 \mathrm{~m} ; 17^{\circ} \mathrm{N} 88^{\circ} \mathrm{E}$ and $19^{\circ} \mathrm{N} 85^{\circ} \mathrm{E}$ ). Numbers are percentages derived from the average counts from $0-60 \mathrm{~m}$.

\begin{tabular}{|c|c|c|}
\hline $\begin{array}{c}\text { Phytoplankton generic } \\
\text { composition }\end{array}$ & $17 \mathrm{~N} 88 \mathrm{E}$ & $19 \mathrm{~N} 85 \mathrm{E}$ \\
\hline Total cell counts $\left(1^{-1}\right)$ & 4594 & 10294 \\
\hline \multicolumn{3}{|l|}{ Diatoms } \\
\hline Amphora & 0.22 & 1.53 \\
\hline Asterionella & --- & 3.96 \\
\hline Bacteriastrum & 0.17 & 1.55 \\
\hline Biddulphia & 3.78 & 14.67 \\
\hline Chaetoceros & 28.30 & --- \\
\hline Climacosphenia & 1.10 & --- \\
\hline Corethron & 0.23 & 2.32 \\
\hline Coscinodiscus & 4.69 & 0.45 \\
\hline Ditylum & 0.88 & 1.27 \\
\hline Eucampia & 0.36 & --- \\
\hline Fragilaria & 1.14 & --- \\
\hline Grammatophora & 0.35 & 0.07 \\
\hline Gyrosigma & --- & 1.53 \\
\hline Leptocylindrus & 0.53 & --- \\
\hline Melosira & 2.33 & 1.52 \\
\hline Navicula & 6.51 & 16.35 \\
\hline Nitzchia & 5.65 & 1.53 \\
\hline Psedonitzchia & --- & 8.02 \\
\hline Rhizosolenia & 7.90 & --- \\
\hline Schroderella & 0.07 & 8.06 \\
\hline Skeletonema & --- & 0.14 \\
\hline Surirella & 0.17 & 0.58 \\
\hline Thallassionema & 4.26 & 30.57 \\
\hline Thallassiothrix & 23.82 & 2.36 \\
\hline Thalassiosira & 0.30 & 1.24 \\
\hline Unidentified & 1.37 & --- \\
\hline \multicolumn{3}{|l|}{ Dinoflagellates } \\
\hline Ceratium & 1.25 & --- \\
\hline Dinophysis & --- & 0.21 \\
\hline Goniaulax & 0.44 & --- \\
\hline Peridinium & 3.53 & 2.01 \\
\hline Prorocentrum & 0.66 & 0.07 \\
\hline
\end{tabular}


Table 2.

Primary productivity and chlorophyll $a$ values from the Arabian Sea and Bay of Bengal determined during southwest monsoon by following JGOFS protocols.

\begin{tabular}{|l|c|c|l|}
\hline \multirow{2}{*}{ Arabian Sea } & PP $\left(\mathrm{mgCm}^{-2} \mathrm{~d}^{-1}\right)$ & \multicolumn{1}{|c|}{$\begin{array}{c}\text { Chlorophyll } a \\
\left(\mathrm{mg} \mathrm{m}^{-2}\right)\end{array}$} & \multicolumn{1}{|c|}{ Reference } \\
\hline \multirow{3}{*}{ Shelf } & $440-1760$ & $16-88$ & Bhattathiri et al. (1996) \\
\cline { 2 - 4 } & $800-2800$ & $33-54$ & Veldhuis et al. (1997) \\
\cline { 2 - 4 } & $449-2668^{\S}$ & $0.63-1.66 \mathrm{mg} \mathrm{m}^{-3} * \S$ & Owens et al. (1993) \\
\hline \multirow{3}{*}{ Offshore } & 770 & $34-44$ & Bhattathiri et al. (1996) \\
\cline { 2 - 5 } & $770-1782$ & $26-60$ & Prasanna Kumar et al. (2001) \\
\cline { 2 - 5 } & $1320-1590$ & $0.09-1.31 \mathrm{mg} \mathrm{m}^{-3 *}$ & Barber et al. (2001) \\
\hline Bay of Bengal & $236-533^{\S}$ & $0.17-0.4 \mathrm{mg} \mathrm{m}^{-3} * \S$ & Owens et al. (1993) \\
\hline Shelf & $39.7-502.0$ & $11-19$ & This study \\
\hline Offshore & $89.4-220.7$ & $9-11$ & \\
\hline
\end{tabular}

*Column values not available

$\S$ Values for September-October 


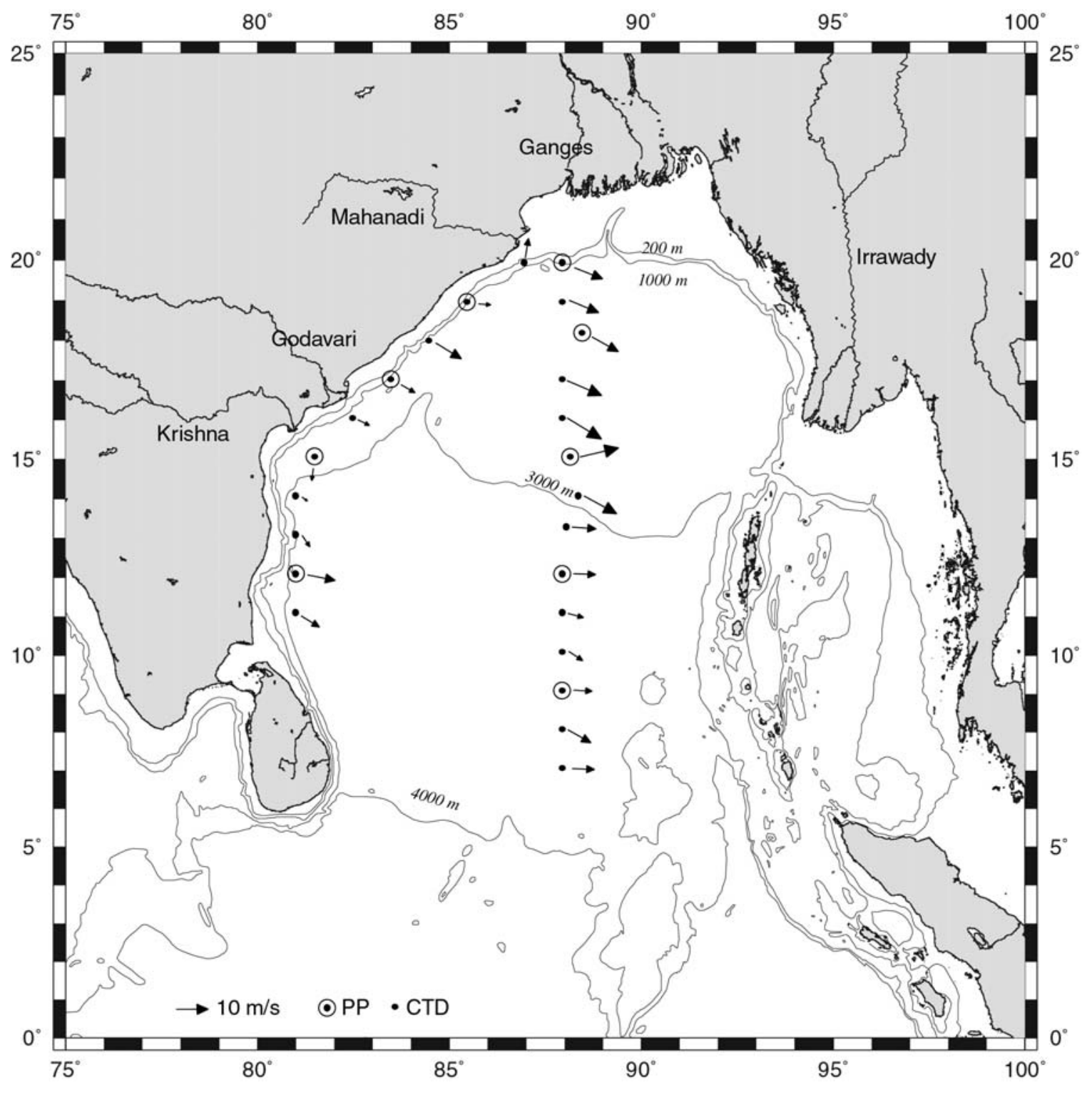

Fig.1 

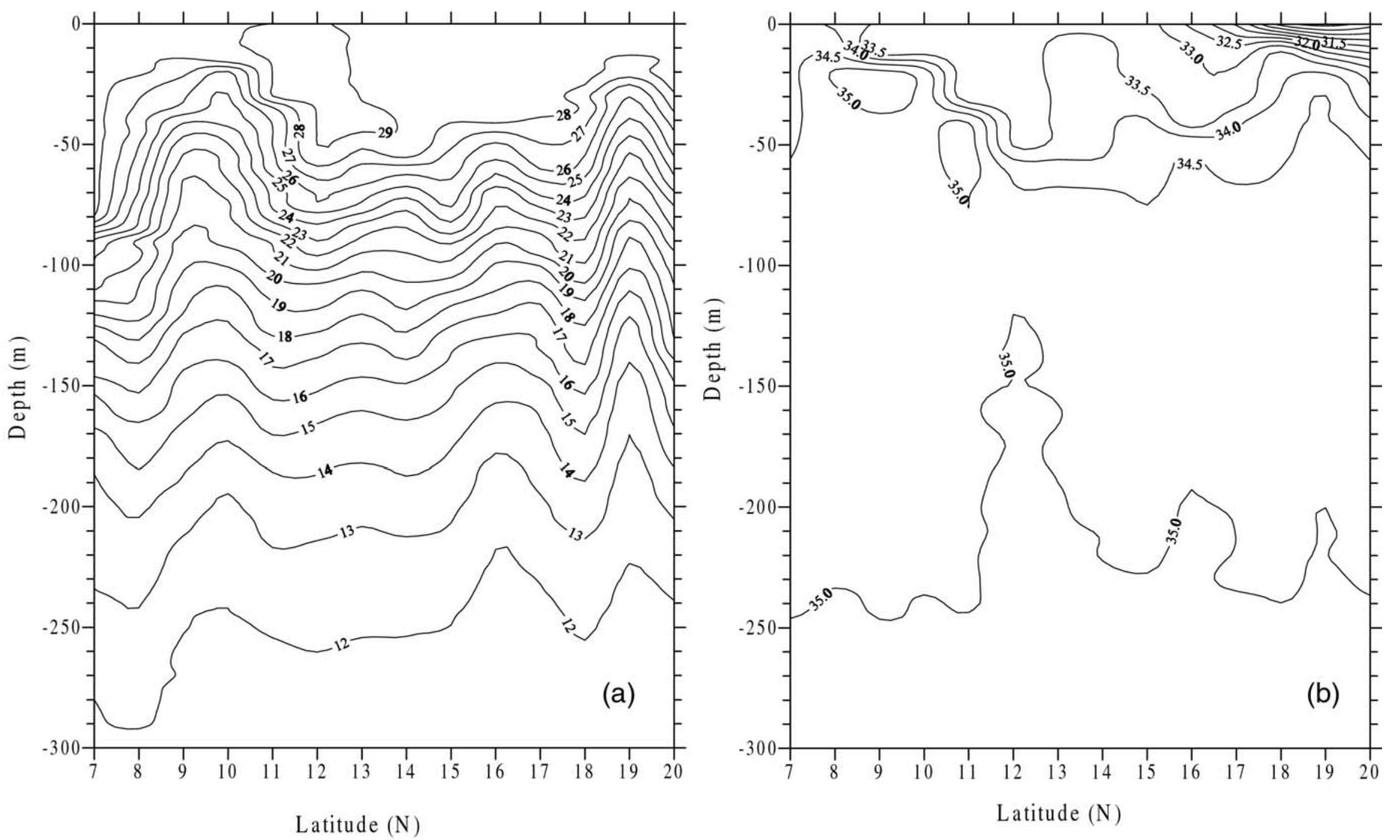

Fig. 2 

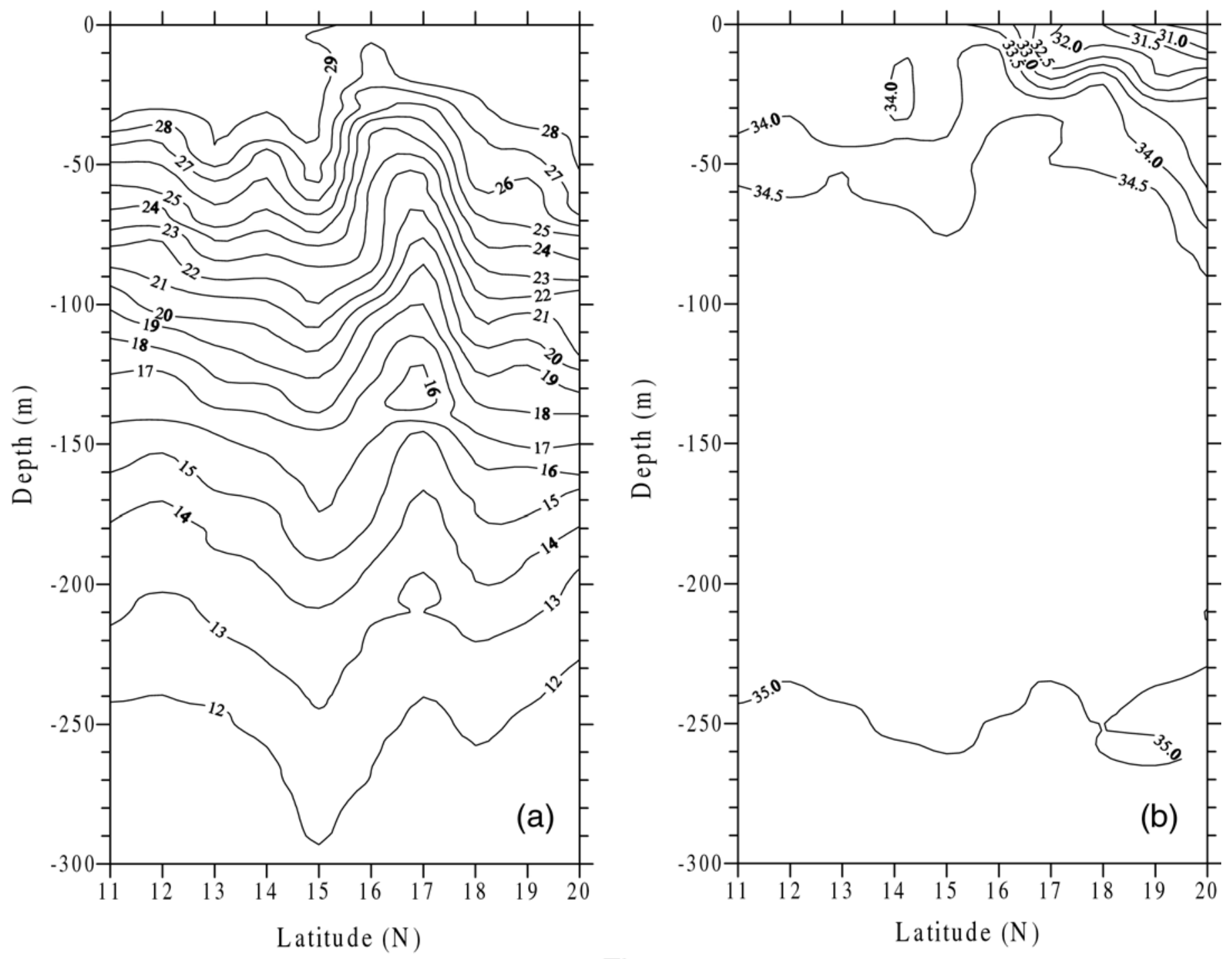

Fig. 3 
(a)

(b)
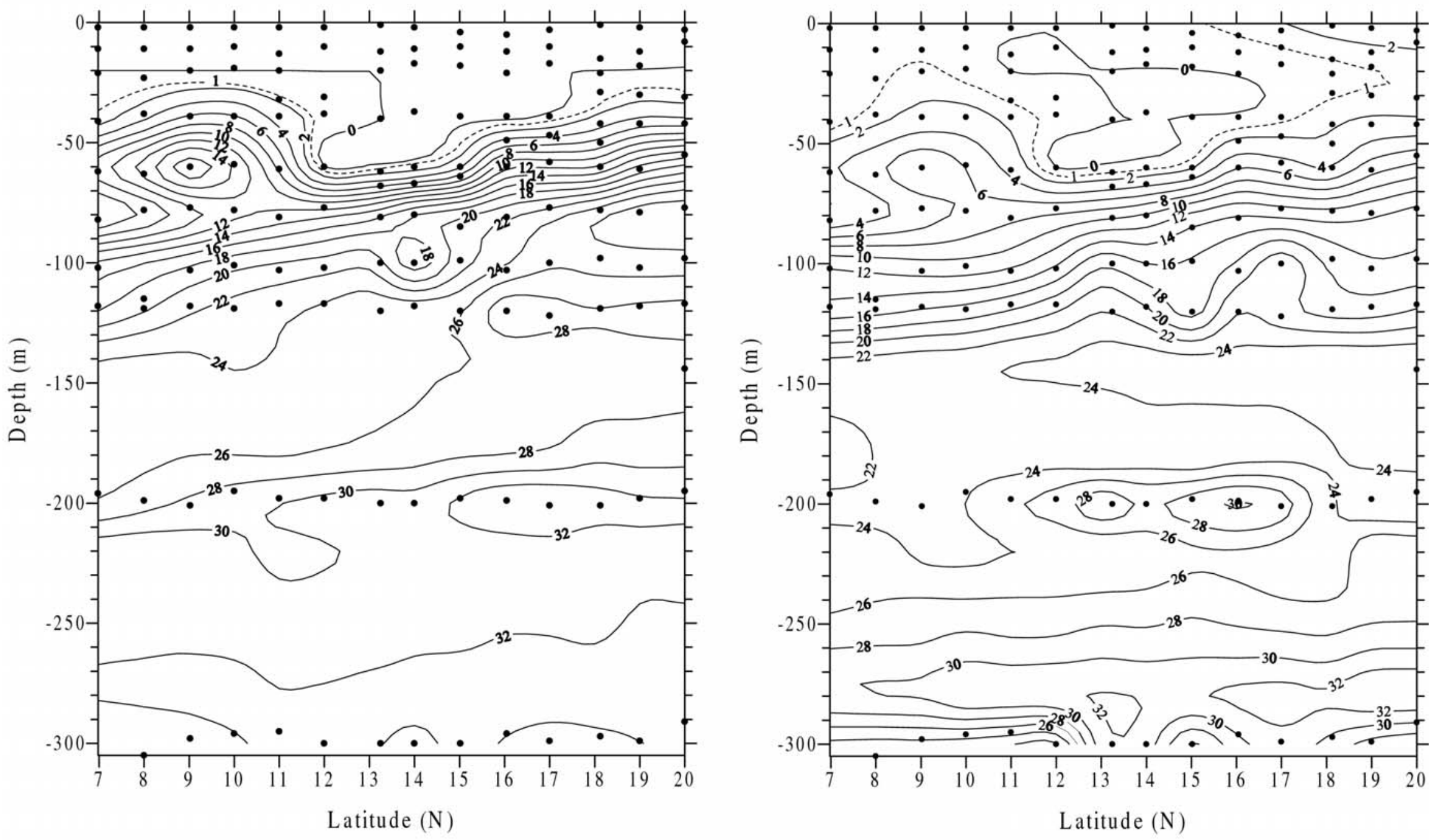

Fig. 4 
(a)

(b)
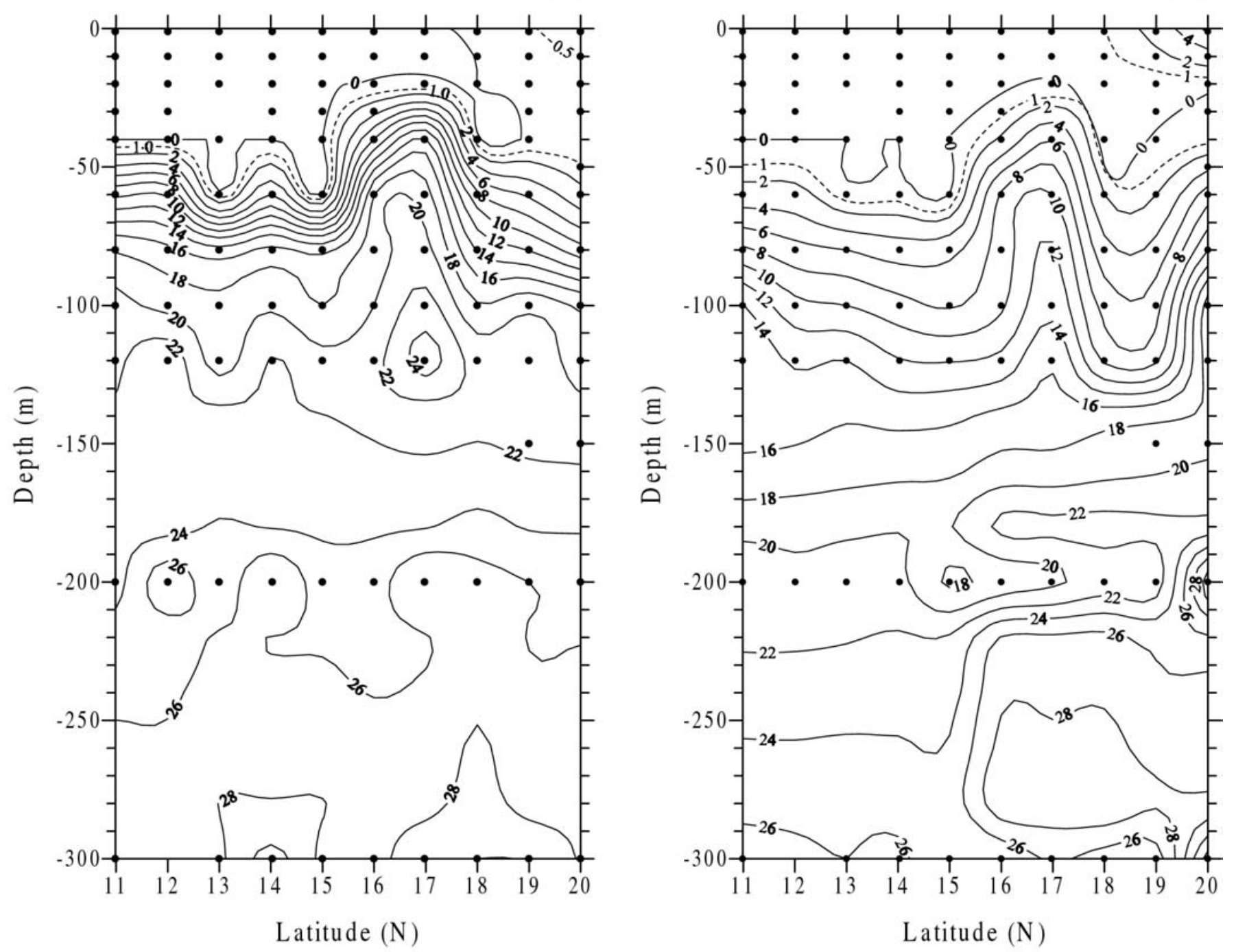

Fig. 5 

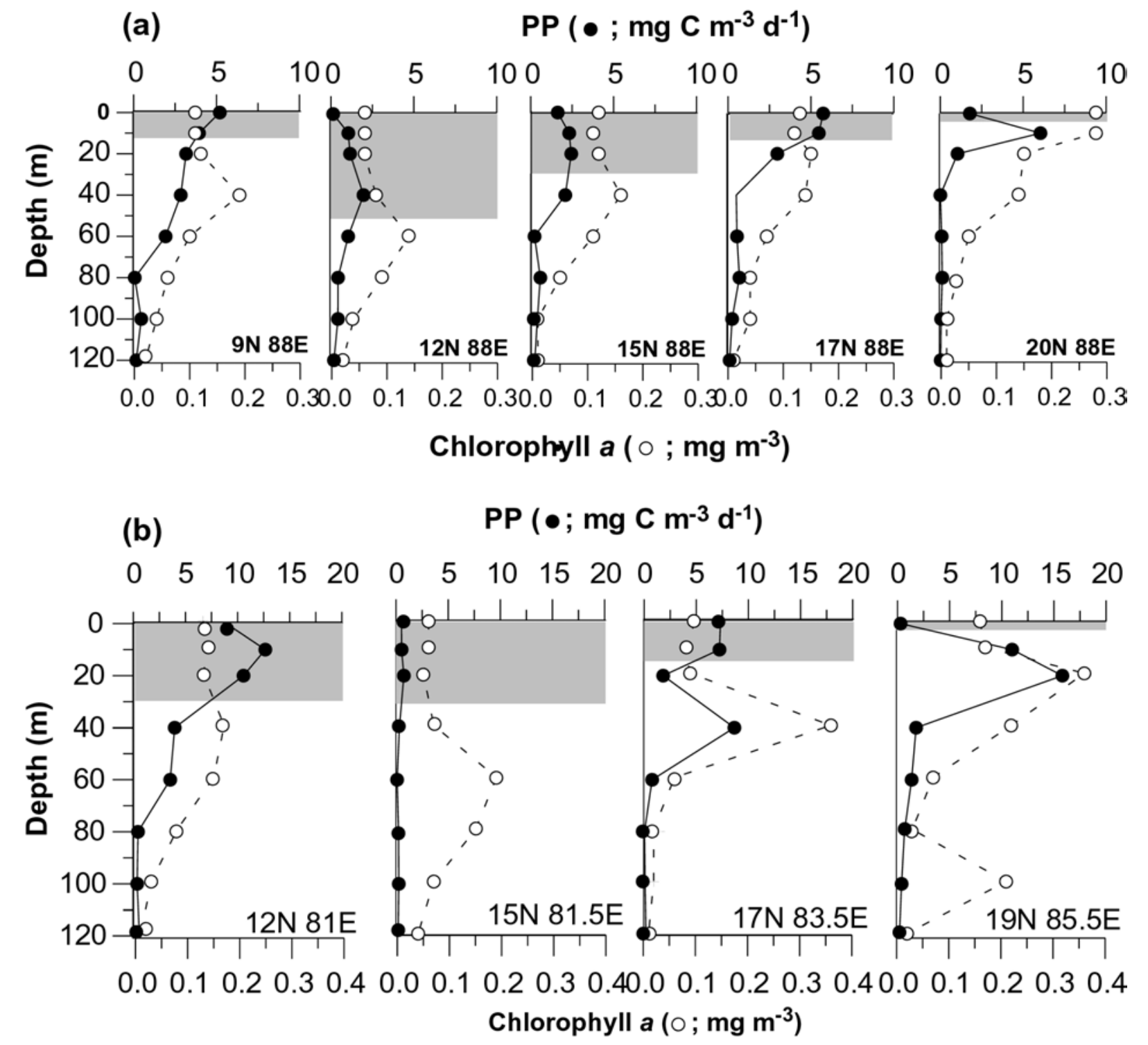

Fig.6 


\section{Coastal}
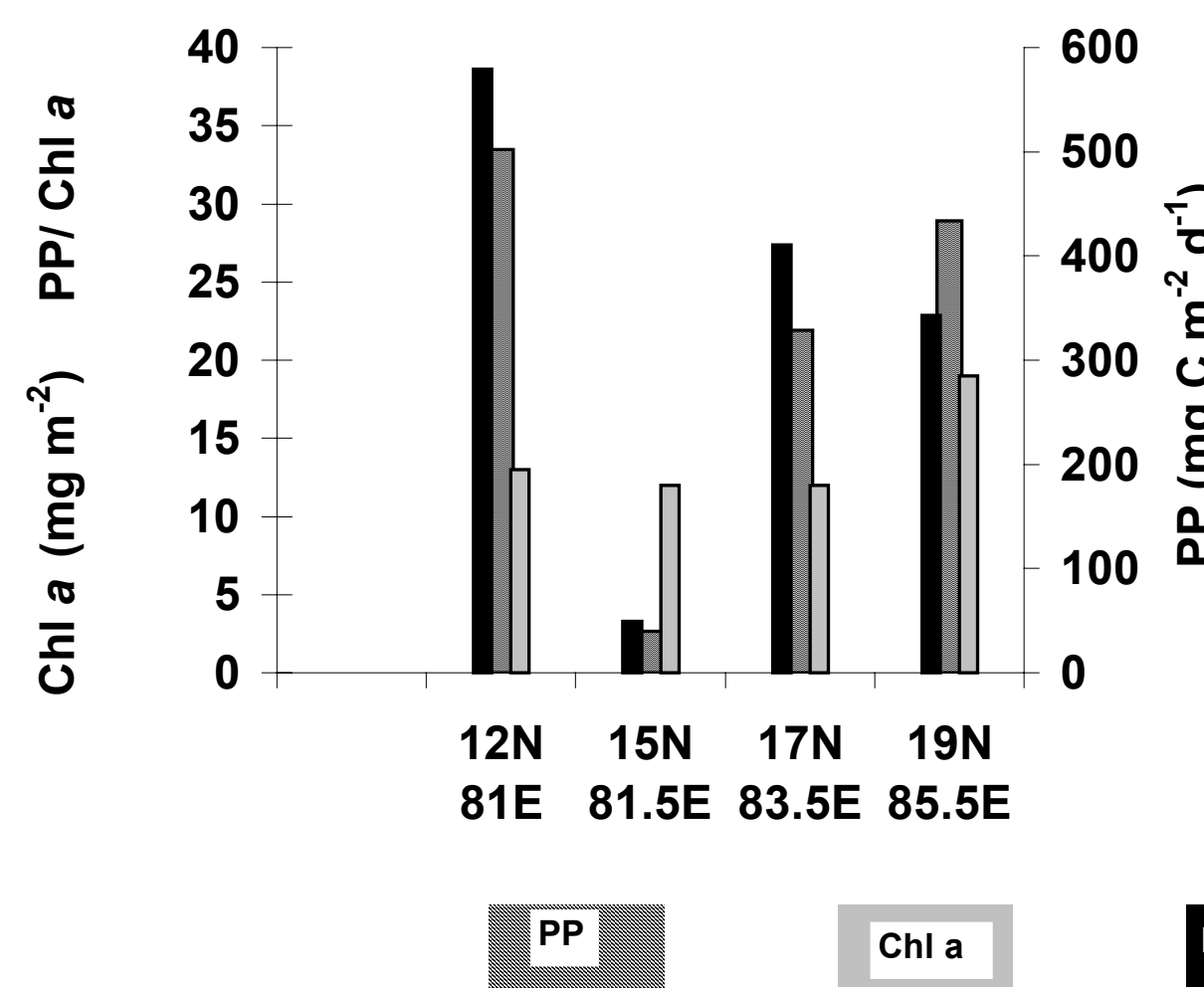

ChI a

\section{Oceanic}

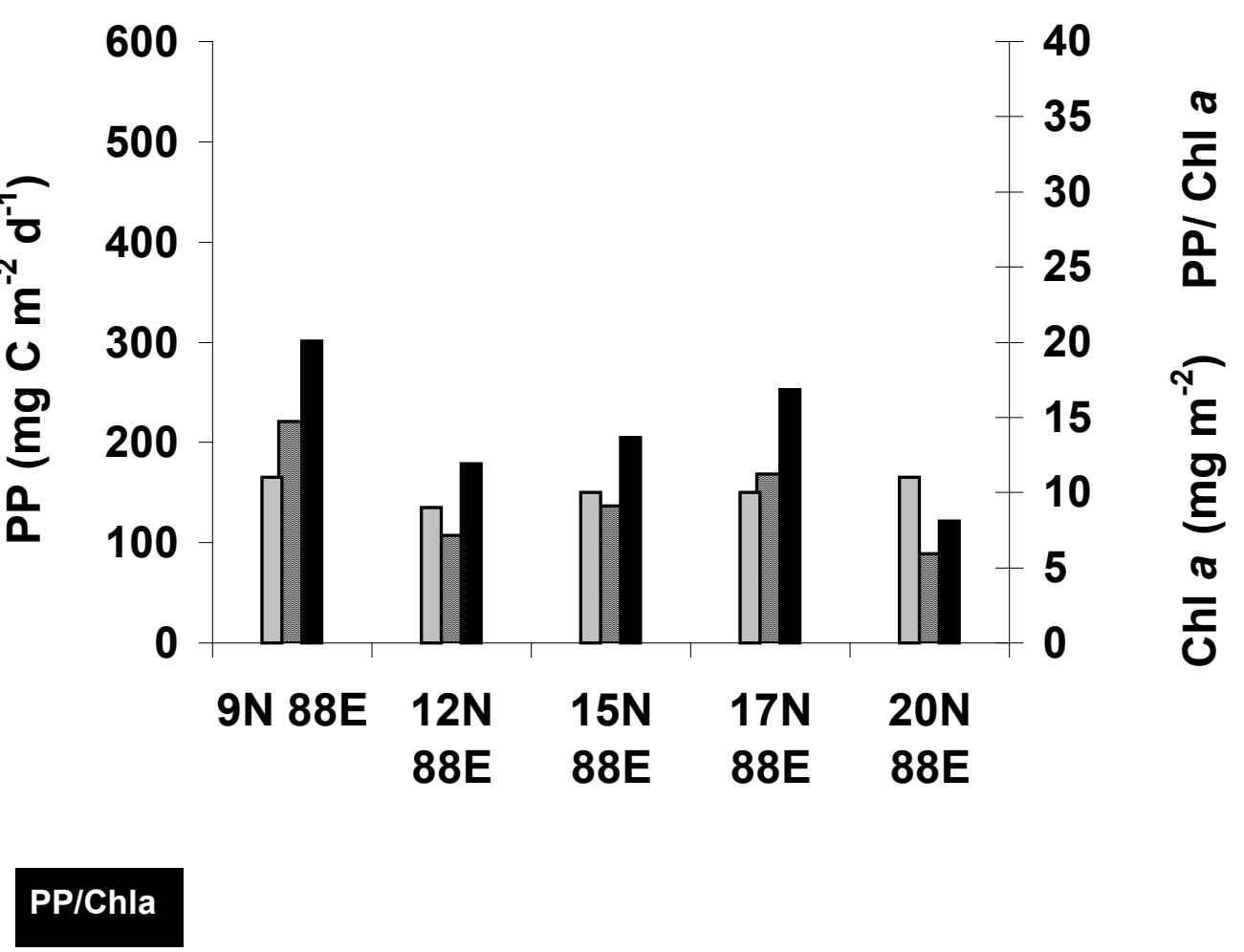

Fig.7 


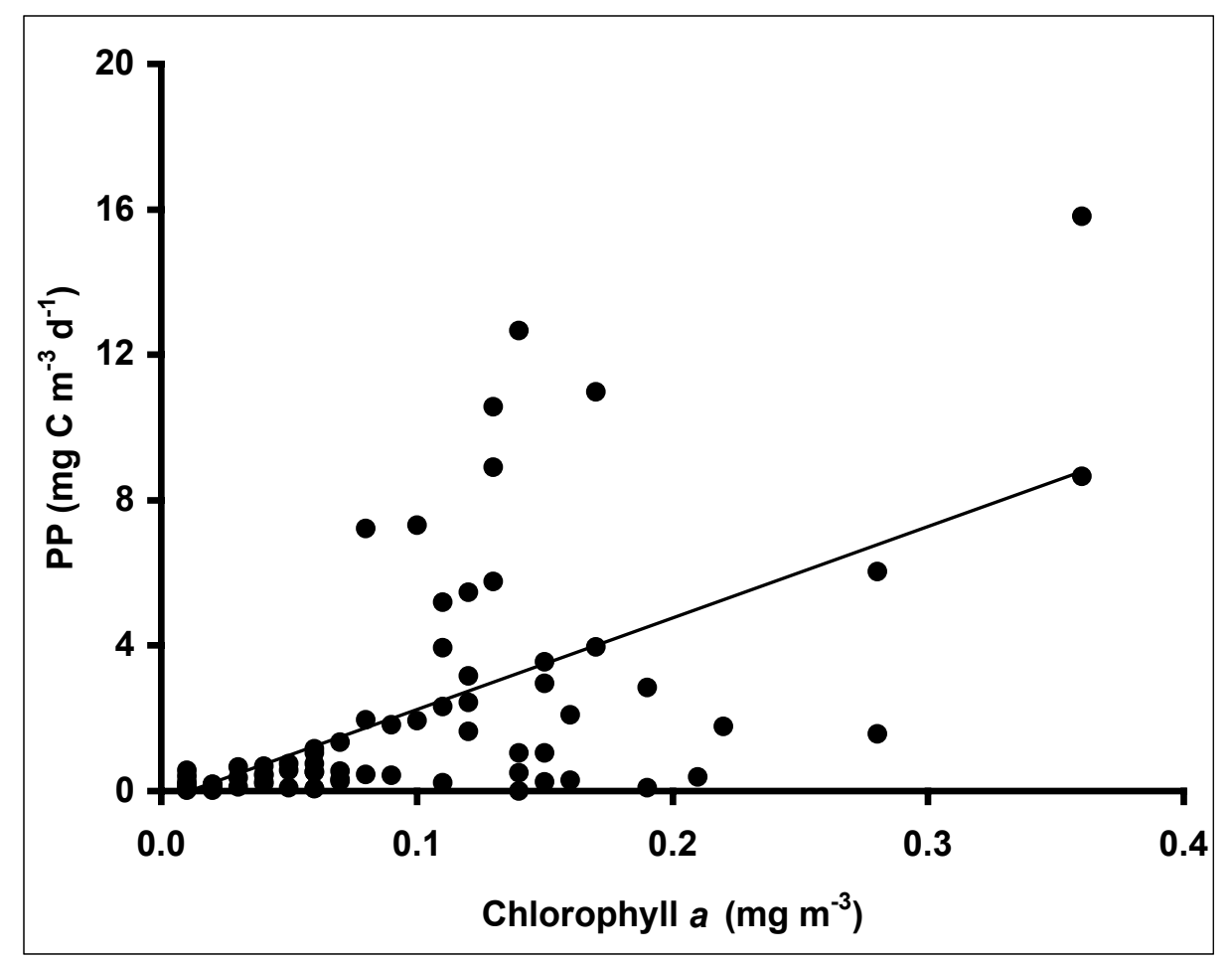

Fig. 8

30 


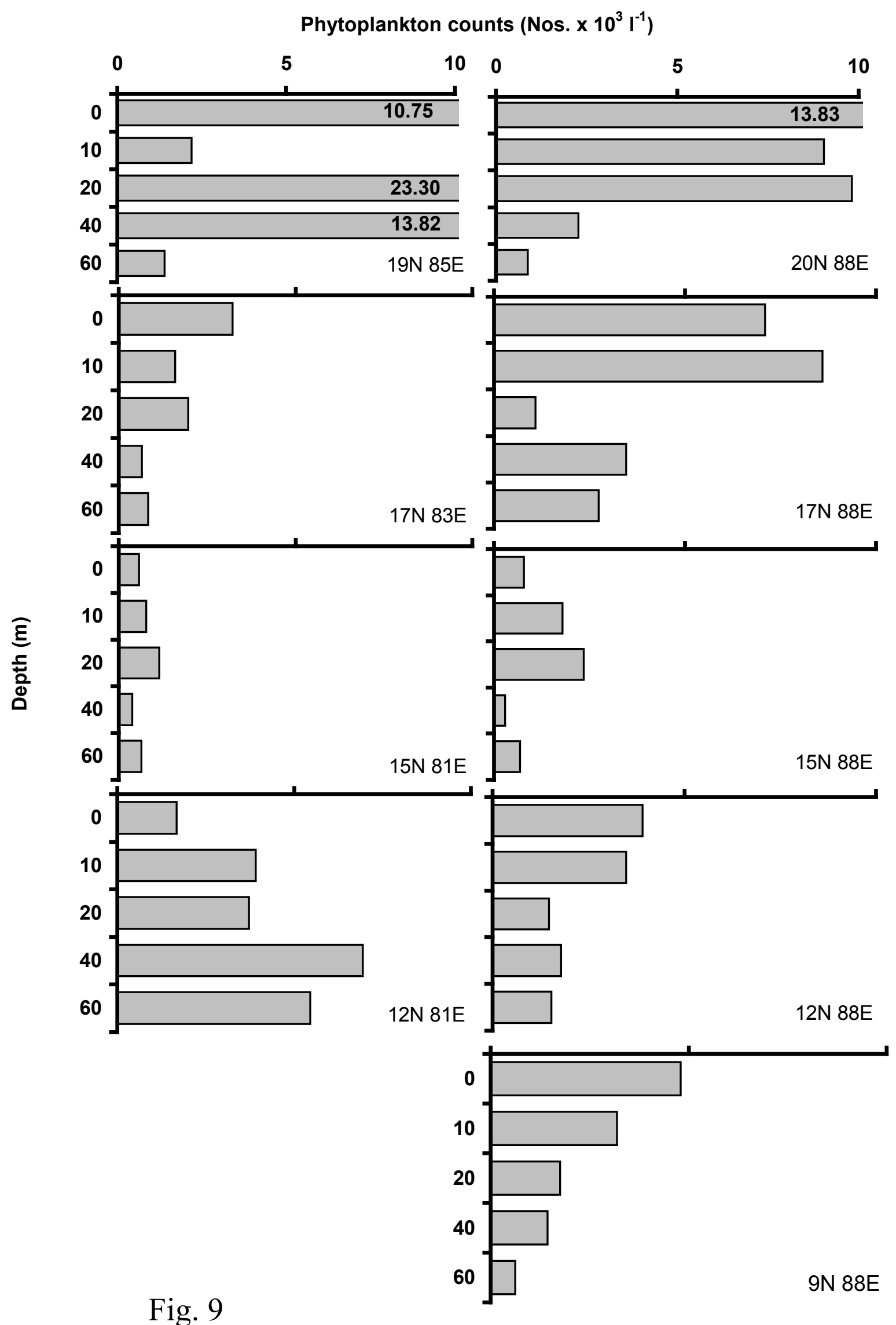

